\title{
Crossref Similarity Check \\ The Firm's PeRformance in Relation to Capital Structure and Foreign OWNership: EVIDENCE FROM VIETNAM
}

\author{
Duy Suu NGUYEN ${ }^{1, *}$, Viet Dan NGUYEN ${ }^{1}$, Duc Thanh TRAN ${ }^{1}$, \\ Michael Joseph DEMPSEY $Y^{1}$
}

\author{
${ }^{1}$ Faculty of Finance and Banking, Ton Duc Thang University, Vietnam \\ *Corresponding Author: Duy Suu NGUYEN (Email: nguyenduysuu@tdtu.edu.vn) \\ (Received: 28-Dec-2020; accepted: 15-Mar-2021; published: 31-Mar-2021) \\ DOI: http://dx.doi.org/10.25073/jaec.202151.315
}

\begin{abstract}
The paper examines the impact of capital structure in the context of foreign ownership on firm performance on non-financial companies in Vietnam between 2008 and 2018. The study employs Pooled OLS, Fixed effect, random effect, and Generalized Least Square to analyze the data. The study finds a non-linear relationship of foreign ownership and firm performance, so that the relationship, which is at first a positive one, becomes negative beyond a certain level of foreign ownership (30-45\% ownership depending on the measure of performance). This insight is then combined with a generally inverse relationship between capital structure and performance. Besides, we find that the firm's size (SIZE) has a positive influence on profitability and financial leverage, while both financial leverage ( $L E V)$ and the number of listed years of company (AGE) impact negatively on firm performance. Furthermore, growth of sale (GROWTH) has a positive effect on the debt ratio, and growth rate (GDP) has a negative effect on financial leverage.
\end{abstract}

\section{Keywords}

Firm performance, capital structure, profitability, foreign ownership, capital ownership form.

\section{Introduction}

Diversification of components in the capital structure plays an important role in funding decisions. Increasing capital composition as well as diversifying forms of ownership helps businesses be more proactive in financing business operations, thereby avoiding risks and reducing mobilization costs. Expanding capital activities, especially foreign investors, is extremely important to an emerging economy like Vietnam. When foreign investors contribute capital to Vietnamese enterprises, in addition to increasing the size of capital for the company, foreign investors have the opportunity to participate in the management of production and business activities, This can increase firm efficiency [1].

At end-2006, 200 companies were listed on the Vietnam stock market with a market capitalization that equated with about $22.7 \%$ of the country's GDP. In 2019, the number of listed companies had increased to 1,662 with a market capitalization of approximately $72.6 \%$ of GDP ( $\$ 149.817$ billion), implying a much greater significance of financial decision making of firms for the Vietnamese economy [2, 3].

In recent years, Vietnam has been viewed as emerging from a frontier market to a secondary emerging market (by FTSE Russell), with addi- 
tional attention from foreign investors and new capital flows. In support, the Vietnamese government has facilitated foreign entry by Decree 60 signed on 26 June 2015 by the Ministry of Finance. Foreign investors now have the ability to own $100 \%$ of a firm's shares. The question of whether foreign ownership has a positive effect on firm performance remains an open one with both company owners and researchers in Vietnam. Khanna and Palepu $[4,5]$ provide evidence that foreign investors foreign are good monitors and perform effectively monitoring roles in frontier markets. In agreement, Nakano and Nguyen [6] find that foreign investors have a positive linear effect with firm value in the Japanese electronic industry. However, Ferris and Park [7], Viet [8], and Phung and Mishra [9] determine a more concave relationship between foreign ownership and firm performance.

Such studies suggest that companies benefit from monitoring by foreign shareholders, with a reduction of agency costs and an enhanced corporate governance, but only up to a point, beyond which a high concentration of foreign ownership leads to conflict between shareholders. Such a non-linear relationship is consistent with corporate government theory that holds that large shareholders have a positive effect due to their monitoring function, but that large shareholders engage in expropriation activities and management entrenchment $[8,10]$.

The above consideration leads us to consider how the interplay between debt ownership, domestic and foreign ownership might actually be maximized to improve firm performance. Few studies have considered such a relationship in the context of Vietnam, to which this paper applies a more complete data set from 2008 to 2018 of 324 non-financial firms listed on Ho Chi Minh City Exchange (HOSE). In addition, by allowing capital structure as a dependent variable and foreign ownership as an independent variable, we examine the impact of foreign ownership on capital structure. The research thereby contributes by providing evidence and support for financial decision-making by both investors and corporations in Vietnam.

The remainder of the paper provides a literature review (Section 2), before presenting the paper's research method (Section 3), our empirical results (Section 4) and our conclusions (Section 5).

\section{Literature review}

\subsection{Theoretical framework}

Jensen and Meckling [11] and Jensen [12] are commonly used to explain the potential conflict between principal (shareholders) and agent of principal (company's managers), which arises when the interests of managers do not align with those of shareholders. As a result, shareholders incur agency costs to mitigate such agency problems with a potential detrimental effect on firm performance. Kraus and Litzenberger [13] argue that a firm will seek an optimal level of debt as a trade-off between costs of debt (of bankruptcy and financial distress) and the tax benefits of debt $[14,15]$ aimed at maximizing firm value. Myers and Majluf [16] based on asymmetric information, consider a hierarchy in financing activities so that firms prefer internal to external financing and prefer issuing new debt to issuing equity shares.

\subsection{Firm performance}

Firm performance is understood here as the ability of a business to make profits from their activities. As proxies for such performance, we use two measures: the accounting "return on assets" (ROA) measure as an evaluation of accounting earnings in relation to total book assets, and Tobin's Q as the market's valuation of the firm in relation to its book value.

Gleason et al. [17] highlight the importance of firm performance on assets (ROA), revenue growth (GSales), and income before tax (PTax) in assessing firm performance. Ahmad et al. [18] consider that short-term debt has a positive impact on ROA while an increase in the debt ratio leads to a lower measure of the accountant's "return on equity" (ROE) for the construction industry. Zeitun and Tian [19] consider that the firm's capital structure is the main factor affect- 
ing the performance of the company as (ROA) and Tobin's Q.

\subsection{Foreign ownership and firm performance}

The relationship between ownership structure and firm performance has been discussed at length following Jensen and Meckling's [11] claim that ownership structure impacts firm value. Specifically, large shareholders have incentives to monitor the manager's activities, which helps to mitigate the issue of agency and thereby maximize firm value. For example, Khanna and Palepu $[4,5]$ investigate the roles of foreign investors in India, and draw attention to a monitoring role of corporate governance by foreign investors in particular. Again, Kim et al. [20] argue that foreign investors in Korea are significant in improving corporate governance.

For emerging economies, it appears that capital from foreign individuals and organizations has had a significant impact on the profitability and business performance of enterprises. Thus, Boardman et al. [21] argue that the increase in capital of multinational companies and the increase in indirect investment in domestic companies has contributed significantly to their performance.

Various studies find that there is a positive relationship between foreign ownership and firm performance. For example, Nakano and Nguyen [6] find a positive linear relationship between foreign ownership and the firm performance measures ROA and Tobin's Q in the Tokyo Stock Exchange. Vo [22] finds a positive association between ownership by foreign investors and firm performance in Vietnam. Viet [8], Phung and Mishra [9] also find a positive relationship between foreign ownership and firm performance.

When foreign ownership is large and concentrated, such share ownership gains managerial power and control over shareholder rights, leading to an entrenchment effect whereby their interests do not align with those of other shareholders, leading to conflict between majority shareholders and minor shareholders [10, 23]; for which the outcome is likely to be a negative impact on firm performance.

A number of studies suggest a non-monotonic relationship between foreign ownership and firm performance. Thus, Ferris and Park [7] examine the relation between Tobin's Q and foreign equity ownership for a sample of 945 industrial firms listed in the 1st Section of the Tokyo Stock Exchange and find evidence of a significant curvilinear relation between $\mathrm{Q}$ and the fraction of common stocks owned by foreigners in Japan. Specifically, Q rises until foreign ownership reaches approximately $40 \%$ to $45 \%$ and then falls back. Viet [8] also finds a significant inverted U shaped relationship between foreign ownership and firm performances for Vietnamese firms, while Phung and Mishra [9] also report a non-linear relationship between ownership structure and firm performance, where, firm performance increases with an increase of foreign ownership up to a level of $43 \%$ and then decreases.

\subsection{Capital structure and firm performance}

Capital structure refers to the combination of equity and debt used by a company to finance its assets [24]. Debt may include funds sourced from the market or financial institutions and equity can include common stock, preferred stock or retained earnings.

Studies examining the impact of capital structure on firm performance have reported mixed results. Thus, Ahmad et al. [18] finds that total debt has a significant negative impact on ROA for Malaysian firms. Zeitun and Tian [19] using panel data, determine that a firm's capital structure had a significantly negative impact on the firm's performance measures, in relation to both accounting and market measures. Nevertheless, Burja [25] finds that the ratio of debt in total assets has positive impact on firm performance. 


\subsection{Foreign ownership and capital structure}

Foreign ownership can provide an important catalyst for ownership structure as it impacts financial decisions. For example, Douma et al. [1] provide evidence of the benefits of foreign corporate holdings that follows from superior monitoring abilities, resource endowments, and skills to use the institutional environment to their advantage, in addition to providing know-how, technology, new markets, new distribution channels, and the ability to reach new capital markets and creditors.

Gurunlu and Gursoy [26] determine that foreign owners are exposed to additional risks such as country risk, currency risk, business risk as compared with domestic owners. Thus, foreign owners will seek to minimize or at least control the risks of foreign direct investment by influencing the governance system of the firms in which they have a stake. To this end, they may seek to have a controlling or at least influencing power on the board of directors.

Li et al. [27] with data from non-publicly traded Chinese firms, find that foreign ownership is negatively related to all measures of leverage, which they explain by arguing that firms with concentrated foreign ownership have more diversified financing sources from which to access capital due to the reputations and relationships of foreign owners. In addition, firms with foreign ownership have lower corporate tax rates leading to less use of debt following from lower potential tax shield savings. Le [2] and Thai [28] also find a negative impact between foreign ownership and capital structure, and report that foreign owners play a monitoring role in corporate governance.

\section{Methodology}

\subsection{Data}

The database for the study relates to 324 companies listed on the Ho Chi Minh Stock Exchange (HOSE) in the period 2008 to 2018. We also collected data from the Worldbank website and financial statements for the companies, including income reports, annual reports and balance sheets.

\subsection{Hypotheses and models}

The results of previous studies considered above have indicated a negative relationship between capital structure and firm performance [3, 18]. This research paper continues to seek the relationship between capital structure and firm performance in Vietnam. With similar business characteristics and macro situation. Therefore following such studies, we propose:

H1: Capital structure has negatively effect on firm performance

which we actualize with the proposed models:

$$
\begin{aligned}
\text { TOBINQ }_{i t}=\alpha & +\beta_{1} \mathrm{LEV}_{i t}+\beta_{2} \mathrm{FOREIGN}_{i t} \\
& +\beta_{3} \mathrm{SIZE}_{i t}+\beta_{4} \mathrm{GROWTH}_{i t} \\
& +\beta_{5} \mathrm{GDP}_{t}+\beta_{6} \mathrm{AGE}_{i t}+\varepsilon_{i t}
\end{aligned}
$$

$$
\begin{aligned}
\mathrm{ROA}_{i t}=\alpha & +\beta_{1} \mathrm{LEV}_{i t}+\beta_{2} \mathrm{FOREIGN}_{i t} \\
& +\beta_{3} \mathrm{SIZE}_{i t}+\beta_{4} \mathrm{GROWTH}_{i t} \\
& +\beta_{5} \mathrm{GDP}_{t}+\beta_{6} \mathrm{AGE}_{i t}+\varepsilon_{i t}
\end{aligned}
$$

where ROA, TOBINQ, LEV, FOREIGN, SIZE, GROWTH, AGE, GDP are as in Tab. 1, for which $t=1, \ldots, T$ is the time period; $i=1, \ldots, I$ is the firm observations; and $\varepsilon_{i t}=n_{i}+v_{i t}, \varepsilon_{i t}$ is a time-variant effect with $v_{i t}$ as a disturbance term.

Following from the above considered studies, foreign ownership has a potential non-linear impact on firm performance. In this paper, we want to test whether a higher capital increase from foreign investors leads to an increase in operational efficiency, or only to a certain extent, then decrease. Because, as foreign ownership increases, the structure in the board of directors or the board of directors with foreigners may change, and such a change affects agency costs, which in turn may change impact performance. However, when foreign ownership increases to a certain extent, will there be a linear impact on efficiency: 
H2: Foreign ownership has an inverted U-shaped relationship with firm performance

which we operationalize with the proposed models:

$$
\begin{aligned}
\operatorname{ROA}_{i t}=\alpha & +\beta_{1} \mathrm{FOREIGN}_{i t}+\beta_{2} \mathrm{FOREIGN}_{i t}^{2} \\
& +\beta_{3} \mathrm{LEV}_{i t}+\beta_{4} \mathrm{SIZE}_{i t} \\
& +\beta_{5} \mathrm{GROWTH}_{i t}+\beta_{6} \mathrm{GDP}_{t} \\
& +\beta_{7} \mathrm{AGE}_{i t}+\varepsilon_{i t}
\end{aligned}
$$

$$
\begin{aligned}
\text { TOBINQ }_{i t}=\alpha & +\beta_{1} \mathrm{FOREIGN}_{i t} \\
& +\beta_{2} \mathrm{FOREIGN}_{i t}^{2}+\beta_{3} \mathrm{LEV}_{i t} \\
& +\beta_{4} \mathrm{SIZE}_{i t}+\beta_{5} \mathrm{GROWTH}_{i t} \\
& +\beta_{6} \mathrm{GDP}_{t}+\beta_{7} \mathrm{AGE}_{i t}+\varepsilon_{i t}
\end{aligned}
$$

To determine the turning point (maximum point) in the relationships, the relationship between foreign ownership and firm performance is identified as a quadratic one:

$$
y=\alpha+\beta_{1} x+\beta_{2} x^{2}
$$

where $y$ is the firm performance and $x$ is the foreign ownership.

With an increase in foreign ownership, large shareholders have an incentive to monitor a manager's activities, thereby mitigating the issue of agency and tending to maximize firm value $[5,20]$. Thus, it is expected that foreign investors play a monitoring role leading to increased efficiency and an increased firm performance $\left(\beta_{1}>0\right)$.

On the other hand, when foreign ownership is more concentrated, this leads to the entrenchment effects considered above whereby the interests of foreign ownership are not aligned with those of domestic shareholders [10, 23], which could impair firm performance $\left(\beta_{2}<0\right)$.

By differentiating the above quadratic relation, we seek to determine the turning point for $x$ from:

$$
\frac{d y}{d x}=\beta_{1}+2 \times \beta_{2} \times x=0
$$

so that

$$
x=-\frac{\beta_{1}}{2 \beta_{2}}
$$

where, because foreign ownership cannot be negative $(x>/=0)$, we have $\beta_{1}>0$ and $\beta_{2}<0$.

Li et al. [27] find a negative relationship between foreign ownership and leverage in nonpublic firms on the Shanghai Stock Exchange. In addition, Thai [28] finds that foreign ownership is negatively related to the ratio of short debt to total assets and the ratio of total debt to total assets. This paper also examines the relationship between foreign ownership and financial leverage. We therefore propose:

H3: Foreign ownership has negatively effect on capital structure of listed firms in Vietnam

which we actualize with the proposed models:

$$
\begin{aligned}
\operatorname{LEV}_{i t}=\alpha & +\beta_{1} \mathrm{FOREIGN}_{i t}+\beta_{3} \mathrm{SIZE}_{i t} \\
& +\beta_{4} \mathrm{GROWTH}_{i t}+\beta_{5} \mathrm{GDP}_{t} \\
& +\beta_{6} \mathrm{AGE}_{i t}+\varepsilon_{i t}
\end{aligned}
$$

\subsection{The variables}

Two measures for firm performance are used: ROA and Tobin's Q. While Tobin's Q captures the firm's market valuation, ROA represent the firm's book performance. Capital structure and foreign ownership are represented respectively as the explanatory variables LEV and FOREIGN. The additional control variables, SIZE, GROWTH, AGE, and GDP, are also defined in Tab. 1.

\subsection{Methodology}

The data for the study was collected from the company reports for the period 2008-2018 with application of a panel regression analysis model (Panel Data). Depending on the particular focus of the study, we applied three methods of regression following table data as follows: Pooled model (OLS), Fixed Effect Model (FEM), Random Effect Model (REM). To select the most optimal model, we applied two types of testing: a Redundant fixed effect test to test between 
Tab. 1: Synthesis of previous studies on variables and hypotheses.

\begin{tabular}{|c|c|c|c|c|}
\hline Variables & Define & Measure & Previous research & Hypotheses \\
\hline \multicolumn{4}{|c|}{ Dependent variable } & \\
\hline $\mathrm{ROA}$ & $\begin{array}{l}\text { Earning after } \\
\text { tax and in- } \\
\text { terest to to- } \\
\text { tal asset }\end{array}$ & Net income/Total assets & $\begin{array}{l}\text { Le and Phan [3], } \\
\text { Nakano and Nguyen } \\
\text { [6], Viet [8], Ahmad } \\
\text { et al. [18] }\end{array}$ & \\
\hline TOBINQ & $\begin{array}{l}\text { Market firm } \\
\text { asset value }\end{array}$ & $\begin{array}{l}\text { (Market Share price }{ }^{*} \text { Out- } \\
\text { standing shares }+ \text { total book } \\
\text { value of debt)/total assets }\end{array}$ & $\begin{array}{l}\text { Le and Phan [3], } \\
\text { Nakano and Nguyen } \\
\text { [6], Ferris and Park } \\
\text { [7], Viet [8], Phung } \\
\text { and Mishra [9], Vo } \\
\text { [22] }\end{array}$ & \\
\hline \multicolumn{4}{|c|}{ Independent variable } & \\
\hline FOREIGN & $\begin{array}{l}\text { Foreign own- } \\
\text { ership }\end{array}$ & $\begin{array}{l}\text { Percentage of foreign owner- } \\
\text { ship in company }\end{array}$ & $\begin{array}{l}\text { Nakano and Nguyen } \\
\text { [6], Ferris and Park } \\
\text { [7], Viet [8], Phung } \\
\text { and Mishra [9], Vo } \\
{[22], \text { Li et al. [27], }} \\
\text { Thai [28] }\end{array}$ & + \\
\hline LEV & $\begin{array}{l}\text { Leveraged fi- } \\
\text { nance }\end{array}$ & Total debt/total assets & $\begin{array}{l}\text { Le and Phan [3], } \\
\text { Ahmad et al. [18] }\end{array}$ & - \\
\hline \multicolumn{4}{|c|}{ Control variable } & \\
\hline SIZE & $\begin{array}{l}\text { Company } \\
\text { size }\end{array}$ & Logarithm of total assets & $\begin{array}{l}\text { Nakano and Nguyen } \\
\text { [6], Ferris and Park } \\
\text { [7], Viet [8], Phung } \\
\text { and Mishra [9], Vo } \\
\text { [22] }\end{array}$ & + \\
\hline GROWTH & $\begin{array}{l}\text { The percent- } \\
\text { age change in } \\
\text { sales during } \\
\text { the year }\end{array}$ & $\left(\right.$ Sales $_{t}-$ Sales $\left._{t-1}\right) /$ Sales $_{t-1}$ & $\begin{array}{l}\text { Le [2], Ahmad et al. } \\
{[18], \text { Vo [22] }}\end{array}$ & + \\
\hline AGE & $\begin{array}{l}\text { Number of } \\
\text { years listed } \\
\text { on HOSE by } \\
\text { the business }\end{array}$ & $\begin{array}{l}\text { Number of years listed on } \\
\text { HOSE by the business }\end{array}$ & $\begin{array}{l}\text { Phung and Mishra } \\
{[9]}\end{array}$ & + \\
\hline GDP & $\begin{array}{l}\text { Real GDP } \\
\text { growth }\end{array}$ & Data from WorldBank website & & + \\
\hline
\end{tabular}

Pooled OLS and Fixed effect models, and a Haumans test to choose between FEM and REM models. Where a significant heteroskedastic error term existed, we used the GLS to rectify the deviation from classical assumptions. The model is similar to the models applied by Douma et al. [1], Ferris and Park [7], Fitri et al. [29].

\section{Empirical results}

\subsection{Statistical description}

Table 2 presents a statistical summary of the variables. The table indicates that the profitability ratio (ROA) has an average value of $7 \%$, with a maximum $78 \%$ and minimum $-159 \%$, 
Tab. 2: Statistical description of the research variables.

\begin{tabular}{|l|l|l|l|l|l|}
\hline Variable & Obs & Mean & $\begin{array}{l}\text { Std. } \\
\text { Dev. }\end{array}$ & Min & Max \\
\hline ROA & 2,398 & 0.07 & 0.09 & -1.59 & 0.78 \\
\hline TOBINQ & 2,398 & 1.14 & 0.70 & 0.00 & 9.09 \\
\hline GROWTH & 2,398 & 0.29 & 1.75 & -1.00 & 55.06 \\
\hline AGE & 2,398 & 1.63 & 0.72 & 0.00 & 2.94 \\
\hline SIZE & 2,398 & 14.09 & 1.27 & 10.70 & 19.99 \\
\hline LEV & 2,398 & 0.47 & 0.21 & 0.001 & 0.99 \\
\hline FOREIGN & 2,398 & 0.14 & 0.16 & 0.00 & 0.80 \\
\hline GDP & 2,398 & 0.06 & 0.01 & 0.05 & 0.07 \\
\hline
\end{tabular}

Note: The variables FOREIGN,

FOREIGNSQUARE, LEV, SIZE, GROWTH,

$A G E, G D P$ are defined in Tab. 1.

with standard deviation of $9 \%$. Thus, we observe that the ROA ratio is generally low while fluctuating sharply. Tobin's $\mathrm{Q}$ value ranges from 0 to 9.09 , with an average value of 1.14 , revealing that company values are appreciated in the stock exchange. Nevertheless, the average Tobin's Q value in HOSE is lower than for other stock exchanges (for example, Tobin's Q ratio for the Shanghai Stock Exchange has a reported average of 1.41 [30] and Tobin's Q in for the Tokyo Stock Exchange has a reported 2.71 [7].

The Foreign ownership ratio has a mean value of $16 \%$, which is markedly lower than for other countries, for example $46.97 \%$ in Indonesia [29] and $20.97 \%$ in India [31], indicating that the proportion owned by foreign investors of listed firms in Vietnam compared to other countries is not high.

The financial leverage (LEV) has an average of $21 \%$, in the range $0.1 \%$ to $99 \%$, revealing a large fluctuation in the debt structure of companies in the market, with a standard deviation of $0.47 \%$.

\subsection{Correlation}

Table 3 presents the correlation between independent variables, indicating that all correlation coefficients are lower than 0.8 (the largest value is 0.294 ) so that collinearity among the explanatory variables does not appear to be an issue in determining the significance of the individual variables, as distinct from the joint significance of the regression model as a whole. In addition, the variance inflating factor (VIF) for all variables is less than 10 with an average value of 1.17 , indicating that collinearity is not a serious issue in analyzing the empirical results.

\subsection{The effect of capital structure on firm performance}

To begin, the models are estimated by ordinary least squares (OLS). We then use the Fixed Effects Models (FEM) and the Random Effects Model (REM). Tables 4 and 5 present the regression results obtained from each of OLS, FEM, and REM.

We conducted an F-test to choose between OLS and FEM, revealing that FEM is more suitable than OLS allowing that the probability of the Chi-Squared statistic is 0.0000 . Additionally, we used the Hausman test to compare FEM with REM, where the probability of the ChiSquared statistic is 0.0002 , implying that FEM is more appropriate than REM. Thus, we applied FEM to estimate the relationship between financial leverage and profitability.

Lastly, we applied the Wald test to check the variance error in the models. The results show that the probability of the Chi-Squared statistic is lower than 5\%. Following the Wald test, our models have a variance error. For this reason, we use the generalized least squares (GLS) method to overcome the problem.

The impact of the explanatory variables on performance is summarized as follows.

\section{Financial leverage (LEV)}

Tables 4 and 5 indicate a negative relationship between financial leverage and performance as Tobin's Q and ROA. This result is consistent with empirical studies [3, 18]. The outcome can be explained by the financial crisis of 2008, which led to rises in inflation and interest rates in Vietnam. For this reason, interest expenses have significantly affected those businesses using more debt, with operations delayed and inventory unresolved, negatively affecting business performances. In addition, firms with high financial leverage often become overly cau- 
Tab. 3: Correlation matrix.

\begin{tabular}{|l|l|l|l|l|l|l|l|}
\hline & FOREIGN & LEV & SIZE & GROWTH & GDP & AGE & VIF \\
\hline FOREIGN & 1.0000 & & & & & & 1.25 \\
\hline LEV & -0.2015 & 1.0000 & & & & & 1.22 \\
\hline SIZE & 0.2731 & 0.2948 & 1.0000 & & & & 1.30 \\
\hline GROWTH & -0.0042 & 0.0123 & 0.0437 & 1.0000 & & & 1.01 \\
\hline GDP & -0.0036 & -0.0152 & 0.1599 & 0.0300 & 1.0000 & & 1.11 \\
\hline AGE & 0.2155 & -0.0392 & 0.1155 & -0.0876 & 0.2609 & 1.0000 & 1.14 \\
\hline
\end{tabular}

Note: The variables FOREIGN, FOREIGNSQUARE, LEV, SIZE, GROWTH, AGE, GDP are defined in Tab. 1.

Tab. 4: The effect of capital structure on firm performance (ROA).

\begin{tabular}{|l|l|l|l|l|}
\hline Variable & OLS & FEM & REM & GLS \\
\hline LEV & $-0.16806^{* * *}$ & $-0.12478^{* * *}$ & $-0.14907^{* * *}$ & $-0.14806^{* * *}$ \\
\hline FOREIGN & $0.05232^{* * *}$ & -0.00125 & $0.027486^{*}$ & $0.05633^{* * *}$ \\
\hline SIZE & 0.00133 & -0.00028 & 0.000349 & -0.00008 \\
\hline GROWTH & 0.00007 & $0.00181^{* *}$ & 0.00125 & 0.000438 \\
\hline GDP & $0.60453^{* *}$ & $1.05343^{* * *}$ & $0.86756^{* * *}$ & $0.69678^{* * *}$ \\
\hline AGE & $-0.01804^{* * *}$ & $-0.02203^{* * *}$ & $-0.02069^{* * *}$ & $-0.01471^{* * *}$ \\
\hline cons & $0.11666^{* * *}$ & $0.10475^{* *}$ & $0.11072^{* * *}$ & $0.11402^{* * *}$ \\
\hline R-square & 0.1855 & 0.0736 & 0.0709 & \\
\hline F-test & \multicolumn{5}{|c|}{0.000} & 0002 & \\
\hline Hausman & \multicolumn{5}{|c|}{0.000} & \\
\hline \multicolumn{2}{|c|}{ Wald (FEM, GLS) } & \multicolumn{5}{|c|}{} \\
\hline
\end{tabular}

Note: The variables FOREIGN, FOREIGNSQUARE, LEV, SIZE, GROWTH, AGE, GDP are defined in Tab. 1. ${ }^{* * *},{ }^{* *}$ and ${ }^{*}$ denote significance at the 1\% 5\%, 10\% levels, respectively. The $P$-values are in parentheses.

Tab. 5: The effect of capital structure on firm performance (Tobin's Q).

\begin{tabular}{|l|l|l|l|l|}
\hline Variables & OLS & FEM & REM & GLS \\
\hline LEV & $-0.62866^{* * *}$ & $0.14819^{*}$ & -0.03905 & $-0.27035^{* * *}$ \\
\hline FOREIGN & $0.50162^{* * *}$ & $0.41978^{* * *}$ & $0.44081^{* * *}$ & $0.32293^{* * *}$ \\
\hline SIZE & $0.08518^{* * *}$ & $-0.07740^{* * *}$ & -0.01513 & $0.05794^{* * *}$ \\
\hline GROWTH & 0.00064 & $0.01313^{* *}$ & $0.01189^{* *}$ & 0.00470 \\
\hline GDP & $10.8612^{* * *}$ & $7.65325^{* * *}$ & $8.1182^{* * *}$ & $9.01567^{* * *}$ \\
\hline AGE & $-0.18105^{* * *}$ & $-0.05640^{* * *}$ & $-0.09686^{* * *}$ & $-0.13423^{* * *}$ \\
\hline cons & -0.21241 & $1.71542^{* * *}$ & $1.01699^{* * *}$ & -0.01322 \\
\hline R-square & 0.0940 & 0.0246 & 0.0198 & \\
\hline F-test & \multicolumn{5}{|c|}{0.000} & 0002 & \\
\hline Hausman & \multicolumn{5}{|c|}{0.0000} & \\
\hline \multicolumn{2}{|c|}{ Wald (FEM, GLS) } & \multicolumn{5}{|c|}{} \\
\hline
\end{tabular}

Note: The variables FOREIGN, FOREIGNSQUARE, LEV, SIZE, GROWTH, AGE, GDP are defined in Tab. 1. ${ }^{* * *},{ }^{* *}$ and ${ }^{*}$ denote significance at the 1\% 5\%, 10\% levels, respectively. The $P$-values are in parentheses. 
tious when making investment decisions on highyielding projects, thereby impeding wealth maximization and decreasing firm performance.

\section{Foreign ownership (FOREIGN)}

Following the GLS method, FOREIGN has a positive effect on performance (ROA) and (TOBINQ). This result is also consistent with previous studies [6, 22]. A likely explanation is that foreign ownership plays a monitoring role on the firm and thereby influences the firm's performance through activities that help to mitigate agency problems, improve corporate governance and support managers to behave in accordance with the wealth maximizing goals of shareholders. In addition, firms may benefit from foreign investors based on their superior monitoring abilities, resource endowments, and their skills to manipulate the institutional environment to their advantage.

\section{Firm size (SIZE)}

The company size (SIZE) has a positive relationship with performance (TobinQ), but not significantly with the ROA. This result is consistent with previous studies $[8,22]$. This result may explain why large size companies are more likely to raise funds from domestic and foreign investors than are small and medium-sized enterprises, allowing them to invest capital in assets, especially fixed assets and modern equipment to increase working capacity, contributing to an increase in the company's performance.

\subsection{The effect of foreign ownership on firm performance}

We employed a Pooled OLS regression to analyze the non-linear relationship between firm performance and foreign ownership while controlling for other determinants of capital structure, namely, leverage, size, growth, number of years listed on HOSE, and GDP growth rate. The results provide a $\mathrm{R}^{2}$ for the model using Tobin's Q and model using ROA as $9.69 \%$ and $20.79 \%$, respectively. Moreover, the overall Ftests with p-value under 0.05 also indicate a good fit of the models. We then used the Fixed effect model and Random model to deal with the unobserved heterogeneity. Tables 6 and 7 present the regression results of the Pooled OLS, FE and RE models.

To select the better model, we conducted an F-test for choosing between the Pooled OLS model and the FE model. The F-test statistic shows that the FE model performs better than the Pooled OLS since the probability of the Chi-Squared statistic is 0.0000 . Next, we conducted the Hausman test for choosing between the Fixed effect model and the Random effect model, for which the probability of the Chi-Squared statistic is 0.0000 , revealing that the Random effect model may generate inconsistent estimators, revealing that the Fixed effect model is more appropriate than either the Random effect model or the Pooled OLS model.

In order to increase the efficiency of the Fixed effect model, we tested for heteroskedasticity in the panel data. The results of the Wald test show that heteroskedasticity exists in the Fixed effect model since the probability of the ChiSquared statistic is less than 0.005 . To deal with such heteroskedasticity, we applied a generalized least squares (GLS) estimation.

\section{Foreign ownership (FOREIGN)}

Foreign ownership measured by the percentage of shares held by the foreign investors has a positive impact on firm performance measured by Tobin's Q (at the $1 \%$ significant level). More specifically, a $1 \%$ increase in foreign ownership is expected to increase Tobin's Q by around $0.73 \%$. Foreign ownership also has a positive impact on ROA at the $1 \%$ significant level, with an increase of foreign ownership by $1 \%$ increasing ROA by around $0.21 \%$. The squared foreign ownership variable is negative at the $1 \%$ significance level. The positive influence of foreign ownership is consistent with others $[6,9,22]$.

It appears, therefore, that when foreign ownership increases, foreign investors are able to impose greater managerial influence with incentives to monitor managers and oblige them to act in alignment with shareholder benefits. However, when foreign ownership reaches a certain level, foreign investors achieve a concentrated ownership and this may impair firm performance. 
Tab. 6: The effect of foreign ownership on firm performance (Tobin's Q).

\begin{tabular}{|l|l|l|l|l|}
\hline Variabiles & OLS & FEM & REM & GLS \\
\hline FOREIGN & $0.832502^{* *}$ & 0.037867 & 0.159128 & $0.73355^{* * *}$ \\
\hline FOREIGNSQUARE & -0.65043 & $0.744034^{*}$ & 0.551538 & $-0.80693^{* * *}$ \\
\hline LEV & $-0.62006^{* * *}$ & 0.1415 & -0.04463 & $-0.25955^{* * *}$ \\
\hline SIZE & $0.081999^{* * *}$ & $-0.07618^{* *}$ & -0.01371 & $0.055874^{* * *}$ \\
\hline GROWTH & 0.000444 & $0.013111^{* *}$ & $0.011894^{* *}$ & 0.004078 \\
\hline AGE & $-0.1834^{* * *}$ & $-0.054^{*}$ & $-0.09525^{* * *}$ & $-0.13848^{* * *}$ \\
\hline GDP & $11.15533^{* * *}$ & $7.453309^{* * *}$ & $7.959222^{* * *}$ & $9.083341^{* * *}$ \\
\hline cons & -0.20314 & $1.729892^{* * *}$ & $1.0212^{* * *}$ & -0.00774 \\
\hline Obs & 2398 & 2398 & 2398 & 2398 \\
\hline R-square & 0.0969 & 0.0260 & 0.0210 & \\
\hline F-test & \multicolumn{5}{|l|}{0.0000} & & \\
\hline Hausman & 0.0000 & \\
\hline Wald & 0.0000 & & \\
\hline
\end{tabular}

Note: The variables FOREIGN, FOREIGNSQUARE, LEV, SIZE, GROWTH, AGE, GDP are defined in Tab. 1. ***, ** and * denote significance at the 1\% 5\%, $10 \%$ levels, respectively. The $P$-values are in parentheses.

Tab. 7: The effect of foreign ownership on firm performance (ROA).

\begin{tabular}{|l|l|l|l|l|}
\hline Variables & OLS & FEM & REM & GLS \\
\hline FOREIGN & $0.2985661^{* * *}$ & $0.064579^{*}$ & $0.149977^{* * *}$ & $0.214842^{* * *}$ \\
\hline FOREIGNSQUARE & $-0.48404^{* * *}$ & $-0.12825^{*}$ & $-0.23949^{* * *}$ & $-0.33396^{* * *}$ \\
\hline LEV & $-0.16165^{* * *}$ & $-0.12364^{* * *}$ & $-0.14732^{* * *}$ & $-0.14681^{* * *}$ \\
\hline SIZE & -0.001035 & -0.0005 & -0.0005 & 0.000566 \\
\hline GROWTH & -0.0000777 & $0.001823^{* *}$ & 0.001209 & 0.000284 \\
\hline AGE & $-0.019792^{* * *}$ & $-0.02245^{* * *}$ & $-0.02127^{* * *}$ & $-0.01504^{* * *}$ \\
\hline GDP & $0.8234145^{* *}$ & $1.087874^{* * *}$ & $0.937934^{* * *}$ & $0.730094^{* * *}$ \\
\hline cons & $0.1235658^{* * *}$ & $0.10225^{* *}$ & $0.112219^{* * *}$ & $0.09555^{* * *}$ \\
\hline Obs & 2398 & 2398 & 2398 & 2398 \\
\hline R-square & 0.2079 & 0.0752 & 0.0717 & \\
\hline F-test & \multicolumn{5}{|l|}{0.0000} & & \\
\hline Hausman & \multicolumn{5}{|l|}{0.000000} & \\
\hline Wald & \multicolumn{5}{|l|}{} \\
\hline
\end{tabular}

Note: The variables FOREIGN, FOREIGNSQUARE, LEV, SIZE, GROWTH, AGE, GDP are defined in Tab. 1. ***, ** and ${ }^{*}$ denote significance at the 1\% 5\%, 10\% levels, respectively. The $P$-values are in parentheses.

Thus, we seek to model:

$$
\begin{aligned}
\text { TobinQ }=-0.0077 & +0.7335 \text { FOREIGN } \\
& -0.8069 \text { FOREIGN }^{2}
\end{aligned}
$$

$$
\begin{array}{r}
\mathrm{ROA}=0.0955+0.2148 \text { FOREIGN } \\
-0.3339 \text { FOREIGN }^{2}
\end{array}
$$

Both models (7) and (8) show that the coefficient value of the foreign variable and the squared foreign variable are both significant at (7) the $1 \%$ level. Thus, we observe a non-linear relationship existing between foreign ownership and the firm performance of listed firms in Vietnam, supporting hypothesis H1. 


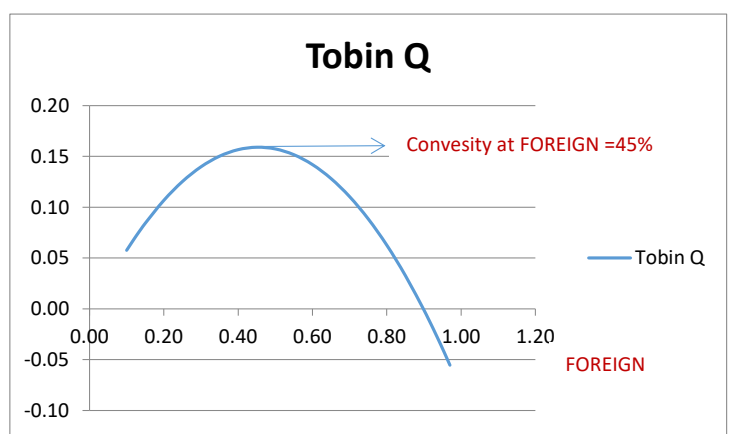

Fig. 1: A non-linear relationship existing between foreign ownership and Tobin Q.

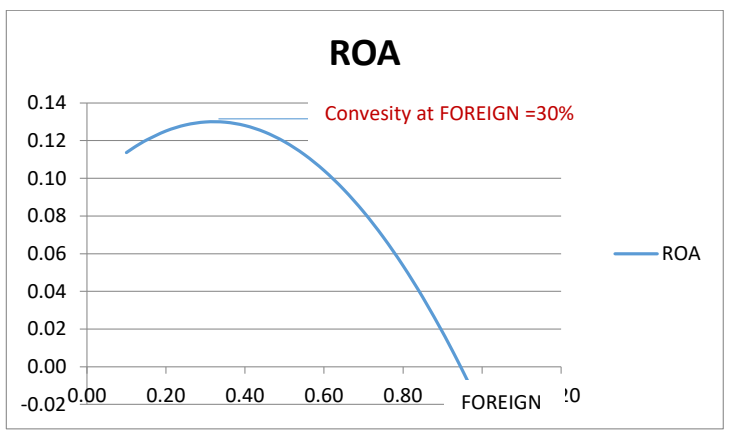

Fig. 2: A non-linear relationship existing between foreign ownership and ROA.

The negative coefficient value of FOREIGN $^{2}$ indicates a concave relation between firm performance and foreign ownership. Thus, firm performance increases with an increase of foreign ownership up to a certain level, to provide a turning point. To calculate the turning points, we used the derivative formula for the model (7) and model (8). The results reveal that Tobin's Q reaches a maximum value when the level of foreign ownership reaches $45.45 \%$, above which Tobin's $\mathrm{Q}$ decreases in Fig. 1. While firm performance measured by ROA increases with an increase of foreign ownership up to $31.63 \%$, above $31.63 \%$ ownership, ROA decreases in Fig. 2. This result is consistent with studies of Ferris and Park [7] and Phung and Mishra [9].

\section{Firm size (SIZE)}

The size of the firm has a positive effect on firm performance. Specifically, a 1\% increase in size is expected to increase Tobin's Q by around $0.05 \%$ and increase ROA by around $0.0005 \%$.
This result is consistent with the empirical results of Nakako and Nguyen [6] and Viet Phan [8]. This outcome may be accounted for by an increase of firm size assisting firms to gain competitive advantage and reputation, thereby assisting firms to improve their performance [32].

\section{Financial leverage (LEV)}

The financial leverage of firms has a negative effect on firm performance at the $1 \%$ significance level. More specifically, the coefficient value in the models for Tobin Q and ROA is -0.2595 and -0.1468 , respectively. In the scope of this research sample, the increase in debt use has not increased the rate of return on assets and company value. It can be said that a joint stock company listed in Vietnam within the research scope uses equity capital better than debt. This result is consistent with the emerging economy and similar to the research results of Nassar S [33] and Kim [34].

\section{Firm age $(A G E)$}

The age of the firm since listing on the HOSE is inversely proportional to firm performance at a $1 \%$ significance level. This may be accounted for by an older firm having a lower performance due to a more outdated relevance to a changing environment [12].

\subsection{The relationship between foreign ownership and capital structure}

To determine the relationship between foreign ownership and capital structure (measured as the ratio between total liability and total assets), we employed a Pooled OLS model. In addition, we applied the Fixed effects model (FEM) and Random effects model (REM) to improve the reliability of the empirical results. Table 8 shows the regression results of the Pooled OLS, FEM, and REM models.

Foreign ownership (FOREIGN): The results show that foreign ownership has a negative effect on the capital structure at a $1 \%$ significance level. This implies that a $1 \%$ increase in foreign ownership is expected to decrease the ratio between total liability and total assets by around 
Tab. 8: The effect of foreign ownership on capital structure.

\begin{tabular}{|l|l|l|l|l|}
\hline Variables & OLS & FEM & REM & GLS \\
\hline FOREIGN & $-0.40623^{* * *}$ & $-0.11656^{* * *}$ & $-0.16351^{* * *}$ & $-0.44652^{* * *}$ \\
\hline SIZE & $0.06507^{* * *}$ & $0.07559^{* * *}$ & $0.069656^{* * *}$ & $0.069253^{* * *}$ \\
\hline GROWTH & -0.00043 & -0.00085 & -0.00086 & 0.000113 \\
\hline AGE & 0.000788 & $-0.02103^{* * *}$ & $-0.01588^{* * *}$ & -0.00234 \\
\hline GDP & $-2.79291^{* * *}$ & $-1.86204^{* * *}$ & $-1.94931^{* * *}$ & $-2.90875^{* * *}$ \\
\hline cons & $-0.21354^{* * *}$ & $-0.42528^{* * *}$ & $-0.34437^{* * *}$ & -0.25669 \\
\hline Obs & 2398 & 2398 & 2398 & 2398 \\
\hline R-square & 0.1772 & 0.0920 & 0.0900 & \\
\hline F-test & \multicolumn{5}{|c|}{0.000000} & \\
\hline Hausman & \multicolumn{5}{|l|}{0.0000} & \\
\hline Wald & \multicolumn{5}{|l|}{} \\
\hline
\end{tabular}

* significant at the $10 \%$ level; ** 5\% level; *** $1 \%$ level.

$0.4465 \%$. This result is consistent with the studies of and Le [2], Gurunlu and Gursoy [26], and Li et al. [27]. This might be accounted for on the basis that foreign investors with resource endowments and relationships can assist firms to have greater opportunities and to be able to diversify their sources of capital [2]. As a result, the demand for external financing may decrease due to the equity sources contributed by foreign investors, thereby allowing firms with an increase in foreign ownership to use less debt in their financial structure.

Firm size (SIZE): The firm size variable has a positive coefficient at the $1 \%$ significance level. Specifically, when firm size increases by $1 \%$, the firm's leverage ratio of firm increases by $0.0692 \%$. This result is consistent with Le [2] and can be interpreted on the basis that larger firms have a well-known reputation and lower credit risk, so that they can more easily borrow or issue bonds as compared with small firms.

Economic growth rate (GDP): We observe that the economic growth rate variable has a negative effect on the capital structure at a $1 \%$ significance level. As the economy grows, the profits of businesses increase, and so the company increases its retained earnings. When the company expands production and business, the company tends to use retained earnings to finance investment. This result is similar to previous research as Coad et al. [35]. Finally, the GROWTH variable has a positive but insignif- icant impact on the capital structure; and the AGE variable has a negative but insignificant effect on the capital structure.

\section{Concluding remarks}

Our research has examined the impact of foreign ownership and financial leverage on firm performance. In addition, we have examined the influence of foreign ownership on financial leverage.

The study finds that foreign ownership impacts positively on both ROA and Tobin's Q. However, foreign ownership does not always lead to an increase in firm performance. Specifically, when foreign ownership exceeds a certain level, the firm's performance decreases. In addition, we find that the firm's size (SIZE) has a positive influence on profitability, while both financial leverage (LEV) and the number of listed years of company (AGE) impact negatively on firm performance. The level of foreign investors affects capital structure in that the more foreign investors, the less the debt. Finally, the firm's size (SIZE) and growth of sale (GROWTH) have a positive effect on the debt ratio, while the number of listed years (AGE) and growth rate (GDP) have a negative effect on capital structure.

Following these results, we recommend, firstly, that investors should allow for the level of foreign ownership as a factor when determining their in- 
vestment decisions, allowing that a high rate of foreign ownership is not always positive to the firm's success. Equally, the firm's board of directors should consider that foreign ownership above a certain level is more likely to be detrimental to the firm's shareholders. We may also recommend that businesses should limit the use of financial leverage to finance the company's operations. And, finally, managers should be aware that while the increase in foreign ownership may decrease the firm's need of financial leverage, such financial leverage appears to act negatively on the firm's performance.

Although achieving certain results, however, the topic is still limited in research methods and research data. In the next research, we can divide the data sample for each specific industry and use the GMM method to check and overcome the indigenousness of the model.

\section{References}

[1] Douma, S., George, R., \& Kabir, R. (2006). Foreign and domestic ownership, business groups, and firm performance: Evidence from a large emerging market. Strategic Management Journal, 27(7), 637-657.

[2] Le, T.P.V. (2015). Ownership structure, capital structure and firm performance: a study of Vietnamese listed firms, University of Western Sydney, Australia.

[3] Le, T.P.V., \& Phan, T.B.N. (2017). Capital structure and firm performance: Empirical evidence from a small transition country. Research in international business and finance, 42, 710-726.

[4] Khanna, T., \& Palepu, K. (1999). Emerging market business groups, foreign investors, and corporate governance. National Bureau of Economic Research Working Paper Series, 6955, 265-294.

[5] Khanna, T., \& Palepu, K. (2000). Emerging market business groups, foreign intermediaries, and corporate governance. In Concentrated corporate ownership, 265-294. University of Chicago Press.
[6] Nakano, M., \& Nguyen, P. (2013). Foreign ownership and firm performance: evidence from Japan's electronics industry. Applied Financial Economics, 23(1), 41-50.

[7] Ferris, S.P., \& Park, K. (2005). Foreign Ownership and Firm Value: Evidence from Japan. Corporate Governance: Advances in Financial Economics, 11.

[8] Viet, P. (2013). Board structure and corporate financial performance: Empirical evidence from Vietnam's listed firms. The Bulletin of The Graduate School of Commerce, Waseda University, 78, 205-231.

[9] Phung, D.N., \& Mishra, A.V. (2016). Ownership Structure and Firm Performance: Evidence from Vietnamese Listed Firms. Australian Economic Papers, 55(1), 63-98.

[10] Shleifer, A., \& Vishny, R.W. (1997). A Survey of Corporate Governance. The Journal of Finance, 52, 737-783.

[11] Jensen, M.C., \& Meckling, W.H. (1976). Theory of the firm: Managerial behavior, agency costs and ownership structure. Journal of Financial Economics, 3(4), 305-360.

[12] Jensen, M.C. (1986). Agency costs of free cash flow, corporate finance and takeovers. American Economic Review, 76(2), 323330.

[13] Kraus, A., \& Litzenberger, R.H. (1973). A state preference model of optimal financial leverage. Journal of Finance, 9, 911-922.

[14] Miller, M.H., \& Modigliani, F. (1963). Corporate income taxes and the cost of capital: A correction. American Economic Review, 53(3), 433-443.

[15] Modigliani, F., \& Miller, M. (1958). The cost of capital, corporation finance, and the theory of investment. American Economic Review, 48(3), 655-669.

[16] Myers, S.C., \& Majluf, N.S. (1984). Corporate financing and investment decisions when firms have information that investors do not have. Journal of Financial Economics, 13(2), 187-221. 
[17] Gleason, K.C., Mathur, L.K., \& Mathur, I. (2000). The interrelationship between culture, capital structure, and performance: evidence from European retailers. Journal of business research, 50(2), 185-191.

[18] Ahmad, Z., Abdullah, N.M.H., \& Roslan, S. (2012). Capital structure effect on firms performance: Focusing on consumers and industrials sectors on Malaysian firms. International review of business research papers, 8(5), 137-155.

[19] Zeitun, R., \& Tian, G.G. (2014). Capital structure and corporate performance: evidence from Jordan. Australasian Accounting Business 83 Finance Journal, Forthcoming.

[20] Kim, I.J., Eppler-Kim, J., Kim, W.S., \& Byun, S.J. (2010). Foreign investors and corporate governance in Korea. PacificBasin Finance Journal, 18(4), 390-402.

[21] Boardman, R., \& Smith, R.A. (1997). Dental implications of oral piercing. Journal of the California Dental Association, 25(3), 200-207.

[22] Vo, X.V. (2015). Foreign ownership and stock return volatility-Evidence from Vietnam. Journal of Multinational Financial Management, 30, 101-109.

[23] Shleifer, A. \& Vishny, R.W. (1986). Large Shareholders and Corporate Control. Journal of Political Economy, 94, 461-488.

[24] Brounen, D., De Jong, A., \& Koedijk, K. (2006). Capital structure policies in Europe: Survey evidence. Journal of Banking \& Finance, 30(5), 1409-1442.

[25] Burja, C. (2011). Factors influencing the companies' profitability. Annales Universitatis Apulensis Series Oeconomica, 13(2), 215-224.

[26] Gurunlu, M., \& Gursoy, G. (2010). The influence of foreign ownership on capital structure of non-financial firms: evidence from Istanbul Stock Exchange. IUP Journal of Corporate Governance, 9(4), 21.
[27] Li, K., Yue, H., \& Zhao, L. (2009). Ownership, institutions, and capital structure: Evidence from China. Journal Of Comparative Economics, 37(3), 471-490.

[28] Thai, A. (2019). The Effect of Foreign Ownership on Capital Structure in Vietnam. Review of Integrative Business and Economics Research, 8(1), 20-32.

[29] Fitri, E.R., Savitri, E., \& Al Azhar, L. (2019). Influence of Foreign Ownership, Ownership Concentrated, and Environmental Disclosure to Firm Value. Indonesian Journal of Economics, Social, and Humanities, 1(2), 91-96.

[30] Ruan, W., Tian, G., \& Ma, S. (2011). Managerial ownership, capital structure and firm value: Evidence from China's civilianrun firms. Australasian Accounting, Business and Finance Journal, 5(3), 73-92.

[31] Ramaswamy, K., \& Li, M. (2001). Foreign investors, foreign directors and corporate diversification: an empirical examination of large manufacturing companies in India. Asia Pacific Journal of Management, 18(2), 207-222.

[32] Pervan, M., \& Višić, J. (2012). Influence of firm size on its business success. Croatian Operational Research Review, 3(1), 213223.

[33] Nassar, S. (2016). The impact of capital structure on Financial Performance of the firms: Evidence from Borsa Istanbul. Journal of Business \& Financial Affairs, 5(2).

[34] Kim, E.H. (1978). A mean-variance theory of optimal capital structure and corporate debt capacity. Journal of Finance, 33, 4563.

[35] Coad, A., Holm, J.R., Krafft, J., \& Quatraro, F. (2018). Firm age and performance. Journal of Evolutionary Economics, 28(1), $1-11$. 


\section{About Authors}

Duy Suu NGUYEN is currently a lecturer and head of Department Investment, Faculty of Finance and Banking, Ton Duc Thang University, Ho Chi Minh City, Viet Nam. He received his B.S degree in accounting and M.S degree in Finance and Banking from the University of Economics Ho Chi Minh City, Viet Nam in 2003 and 2011. He received a Ph.D. degree in Finance and Banking from Banking University of Ho Chi Minh City, Viet Nam in 2017. His research interests include Finance and Banking, Corporate Finance, Monetary policy.

Viet Dan NGUYEN is currently a MBA student in the GMBA Program at National Taipei University, Taiwan, ROC. He received his bachelor's degree in Finance and Banking from Ton Duc Thang University (TDTU), Vietnam in 2020. His research interests include corporate governance, empirical asset pricing.

Duc Thanh TRAN is currently a MBA student at National Taipei University, Taiwan, ROC. He received his Bachelor's degree in finance and banking from Ton Duc Thang University, Viet Nam, in 2020. His research interests include corporate governance, executive compensation.
Michael Joseph DEMPSEY is a Professor of Finance with the Faculty of Finance and Banking at Ton Duc Thang (TDTU) University in Ho Chi Minh City, Vietnam, having joined in 2018. He was previously a Professor and Head of the Finance Discipline at RMIT University in Melbourne, Australia (from early 2013 to end 2017). Prior to this, he was an Associate Professor at Monash University, Australia, before which he was an Associate Professor with Griffith University, Australia, having previously been at Leeds University, UK. He also has many years' experience working for the petroleum exploration industry, in the Middle East, Egypt, Aberdeen and London. $\mathrm{He}$ is an active researcher in seeking to understand the interplay between risk and returns as the essential dynamic of market behaviour; the theoretical implications of taxation for stock valuation; and corporate decision-making as socially constructed. His academic text Stock Markets, Investments and Corporate Behavior (published by Imperial College Press/World Scientific, 2016) summarizes his work in these areas; while his student text Stock Markets and Corporate Finance (published by World Scientific, 2017) was made the core text for Masters students at RMIT. He is also a co-author of the student text Fundamentals of Corporate Finance (published by Wiley (2013, 2nd ed.). 